\title{
EGÉSZSÉGVÉDELEM ÉS TÁRSADALMI \\ FELELŐSSÉGVÁLLALÁS VESZÉLYES IPARI RENDSZEREKBEN
}

\section{STUDY OF CSR AND HEALTH PROTECTION IN DANGEROUS INDUSTRIAL ENVIRONMENTS}

\author{
Bakos Levente ${ }^{1}$ \\ ${ }^{I}$ Sapientia Erdélyi Magyar Tudományegyetem Müszaki és Humántudomány Kar, \\ Gépész Tanszék, Románia, Marosvásárhely/Koronka, Segesvári út 1C; Telefon / \\ Fax:+40-265-206210,levelezésicím:bakos@ms.sapientia.ro
}

\begin{abstract}
The paper presents the results of a study in Tg. Mureș Region, on large companies regarding the CSR and health concerned activities. Based on a wider research on SMEs, the objective of the present study is to compare the CSR concerns and health issues on an average SMEs compared to a large industrial companies where dangerous technologies are used. We assume that the knowledge about the CSR and the health concerns are far more developed in the case of industrial environments.
\end{abstract}

Keywords: CSR, dangerous environment, SMEs.

\section{Összefoglalás}

A dolgozat kiindulópontja egy olyan kis és középvállalatokon végzett tanulmány, amely a vállalati felelősségvállalás és az egészségvédelem kérdéseit elemezte közel háromszáz Marosvásárhely környéki vállalkozás esetében. Ebböl a nagyobb tanulmányból kiindulva, a jelen dolgozat témája, hogy öszszehasonlítsuk az átlagos kis és középvállalatok esetében tapasztaltakat ugyanabban a régióban tevékenykedő, veszélyes környezettel is rendelkező nagy ipari rendszerekkel. Azt feltételeztük, hogy a felelősségvállalás és az egészségvédelem kérdései jelentős mértékben jelen vannak ezekben a rendszerekben.

Kulcsszavak: társadalmi felelösségvállalás, veszélyes technológiák, $K K V-k$

\section{Társadalmi felelősségvállalás, aktualitás, marketing trend vagy PR?}

Az EU által intézményesített megközelítés alapján a társadalmi felelősségvállalás alatt azt ,,az üzleti koncepciót értjük, melynek értelmében a vállalatok - önkéntes alapon - társadalmi és környezetvédelmi szempontokat érvényesítenek üzleti tevékenységük során és partnereikkel fenntartott kapcsolataikban'[1]. A vállalati szociális felelösség (CSR-Corporate Social Responsability, a továbbiakban ezt az általánosan elterjedt rövidítést használjuk) kulcsszerepet játszhat a fenntartható fejlödésben, miközben javíthatja Európa innovációs potenciálját és versenyképességét. Ez gondolatmenet és meghatározás tulajdonképpen az Európai Bizottság egy korábbi, vitaindítónak szánt Zöld Könyvéböl [2] átvett meghatározás. A Bizottság 2001 júliusában tette meg az első igazán fontos lépést CSR-ügyben, ekkor a cél az volt, hogy 
bevezesse a köztudatba a témát, széles körü vitát és eszmecserét generáljon, továbbá, hogy kipuhatolja, hogy milyen partnerekre számíthat a kérdés további napirenden tartásában. A beérkezett mintegy 250 válasz jelezte: óriási az érdeklődés és a fogadókészség a téma iránt.

Mára már a társadalmi felelősségvállalás egyre divatosabb fogalom, olyanynyira, hogy lassan beépül a hétköznapi szóhasználatba. Multinacionális cégek képviselői, helyi és európai rangú politikusok, kormányok és vidéki civil szervezetek gyakran szövik retorikájukba ezt a fogalmat. Ennek okai között minden bizonnyal megtaláljuk a valós vagy vélt társadalmi igényt. Mondhatnánk, hogy a dolgok ezzel rendben is vannak, hiszen a társadalmi felelősségvállalás létjogosultságát ma már kevesen vitatják, függetlenül attól, hogy a fogalom mögött hol a környezetvédelmet, az etikus magatartást vagy a szponzori tevékenységet feltételezzük.

A lényeg az, hogy mindig valami pozitív dolog eléréséről van szó a közjó érdekében. Az utca emberének, de még számos cégvezetőnek is még mindig leginkább az jut eszébe a felelös vállalatról, hogy az az elvárás, hogy támogatni kell a helyi zöld szervezeteket, a diákszövetséget vagy színházat, esetleg a hontalanokkal foglalkozó vagy rákos gyerekeket segítő alapítványt. A szolidaritás kétségtelenül fontos kérdés, szinte genetikai kódunkba íródott szabály, hogy az erősek feladata a gyengék segítése. De azt állítani, hogy például pusztán azérts hadd vegyük példának azt a romániai vállalatot, amelyről még részletesebben is írunk, az Azomureș vegyi üzemet-, mert támogat egy-két élvonalbeli sportegyesületet, ez a cég egy felelős vállalat lenne, nyilvánvaló túlzás. S ha azt is megnéznénk, hogy a profitjának - de inkább az éves forgalmának- hány százalékát fordítja erre, akkor igazán az is kiderül, hogy ez a támogatás lehet, hogy még PR fogásnak is ke- vés, és a tudatos felelősségvállaláshoz semmi köze.

\section{Előzmény: felmérés a társadalmi felelősségvállalás kérdésében KKV-nél}

A szerző vezetésével pár hónapja befejeződött egy olyan kutatás, amely, több mint 300 Marosvásárhelyen és környékén tevékenykedő kis és középvállalat esetében azt vizsgálta, milyen mértékben vannak tisztában a CSR fogalmával és milyen mértékben használják ezt fel a nyilvános és belső kommunikációban. [3], [4]. A KKV-k a következő feltételeknek kellett megfeleljenek:

- a székhely Marosvásárhely Nagyvárosi Övezetben legyen;

- tevékenységi kör: bővebb értelemben vett ipari jellegü tevékenységek (kizártuk a kereskedelem, vendéglátóipar, turizmus, tanácsadás, közigazgatás, szállítás, stb. területeket);

- Alkalmazottak száma minimum 10;

- éves forgalom: min. 65000 euró.

A ténylegesen mért adatok alapján a vizsgált populációban az átlag alkalmazottszám 35 volt, az átlagos formalom pedig 1500000 euró. A vállalatok helyszínén végzett kérdőíves felmérést 35 Sapientiás hallgató végezte el 2013. június-szeptember periódusban. Tekintettel arra, hogy ipari jellegű tevékenységeket vizsgáltunk, a KKV-ra egyébként jellemző alacsony forgalom, illetve az alacsony alkalmazottszám, ezen a területen kevésbé jellemző a vizsgált terület specifikuma miatt. Ezeket az átlagokat lényegesen torzítja a vizsgált közepes vállalatok teljesítménye. A kisvállalatok esetében mért gazdasági mutatószámok sokkal szerényebbek.

$\mathrm{Az}$ 1. ábrán a CSR fogalmának ismertségét mutatjuk be, a cégek éves forgalma függvényében meghatározott csoportokban. 


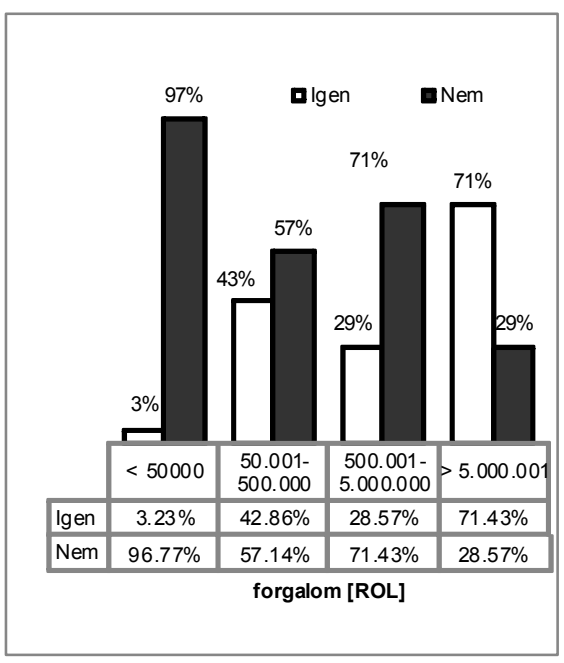

1. ábra. A CSR fogalmának ismerete és a pénzügyi forgalom kapcsolatának vi-szonya az elemzett mintán

A 300 cégből álló mintán mért adatok rosszabb számokat eredményeztek az országos és a nemzetközi szinten, nagyvállalatokon végzett kutatások adataihoz képest. Lásd [5], [6], [7]. Az ábrán az látható, hogy a pénzügyi forgalom növekedésével egyre inkább rendelkeznek a vállalatok vezetői CSR-el kapcsolatos ismeretekkel. Magyarán minél nagyobb egy vállalat, annál inkább odafigyelnek a felelősségvállalás kérdésére. Látható, hogy a kisvállalatok vezetőinek $97 \%$-a nem hallott a CSR fogalmáról, míg a nagyobb vállalatoknál ez a szám $29 \%$-ra csökken.

A mi esetünkben a célpopuláció 1623 cég, a minta reprezentatív, a relatív hiba $\pm 4,87 \%$ és a megbízhatósági szint $95 \%$.

$\mathrm{Az}$ ábrán látható eredmény önmagában az elöre feltételezett eredményt jelenti, sőt a részletesebb elemezések sem mutattak számottevő eltéréseket. Tovább elemezve az adatokat, abban sem tapasztaltunk ellentmondást, hogy hipotézisként feltételeztük, hogy az egészséggel, munkavédelemmel kapcsolatosan a vállalatok nem éreznek kényszert arra, hogy többet tegyenek, mint a törvényes elöírás. Erre vonatkozóan igen kifejező a 2. ábrán bemutatott helyzet.

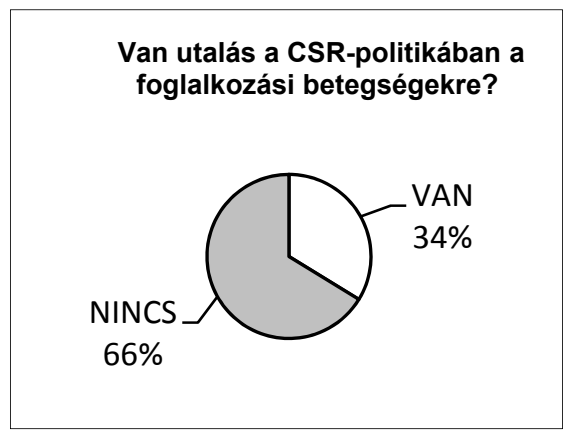

2. ábra. $A$ vizsgált vállalatok CSR-politikája és a foglalkozási megbetegedésekre vonat-kozó felelösségvállalás

Azok közül a vállalatok közül, ahol létezik valamilyen szintü CSR tevékenység ez a vizsgált vállalatok alig 40\%-a -, nos ezen vállalatok közül is több mint $66 \%$ nem gondolt az egészségvédelemmel kapcsolatos CSR-lehetőségekre. Amenynyiben csak a fent felsorolt néhány adatból indulunk ki, már akkor is felmerül a kérdés, hogy vajon mi lehet a helyzet ugyanazon a földrajzi területen elhelyezkedő nagyvállalatok esetében. A kis és közepes vállalatok esetében nyilvánvalóvá vált, hogy a vállalat növekedésével a CSR egyre fontosabb kérdés. Ugyanakkor néhány látványos kivételtől eltekintve alig van tudatosság a CSR-tevékenységekben, és a specifikusan vizsgált egészségvédelmi/munkavédelmi kérdésekben szinte teljes hiány mutatkozott. Ez ellentmond a nagyvállalatokon végzett, hazai vagy nemzetközi kutatásoknak. Lásd [5], [7].

További kérdéseket vet fel az, hogy az előző KKV-t vizsgáló kutatás hipotéziseiben nem szerepelt hangsúlyosan a földrajzi helyzet, csak a méret. Továbbá a minta reprezentativitása érdekében akkor nem kerestük azokat a vállaltokat, amelyekben magas kockázattal járó ipari tevékenység folyik. Ennek eredményeképpen fogalma- 
zódott meg a jelen dolgozatban nagyvállalatokat elemző kutatás gondolata.

\section{Egészségvédelem és felelősség- vállalás nagy ipari vállalatoknál}

Az alcímben, illetve tulajdonképpen a fócímben is megfogalmazott vizsgálati halmaz a valóságban lényegesen komplexebb és szükebb is. Tulajdonképpen olyan nagyvállalatokat elemzünk a vállalásuk alapján - s ezt a nyilvános megjelenések elemzésére építjük -, amelyekben veszélyesnek tartott, magas kockázatú ipari folyamatok zajlanak. Két további kiválasztási kritérium volt az, hogy azon a földrajzi területen tevékenykedjenek, mint az elöző kutatásban levő populáció, és az, hogy lehetöleg egy nagy multinacionális holdinghoz tartozzanak. Az első szempont azért lényeges, mert össze lehet hasonlítani a kis vállalatoknál kapott eredményekkel, az utóbbinak meg azért van értelme, mert lehetőség adódik a helyi vállalat és az anyavállalat CSR-koncepciójának az összehasonlítására. A továbbiakban a vizsgált vállalatok közül bemutatunk néhányat.

\subsection{Azomureş vegyi kombinát}

Az 1962-ben alakult vállalat a legnagyobb mütrágyatermelö Romániában. Jelenleg a kombinát három termelöüzemből áll: ammónia, ammónium-nitrát és a salétromsav gyártó üzemekből. A gyár 1966-tól elsősorban mütrágyaféléket és a müanyagiparban használt melamint gyárt. A rendszerváltás után folyamatosan átalakult, privatizálták, és végül 2012-től az új tulajdonos az Ameropa AG svájci konszern.

A honlapon [8] a CSR-re vonatkozó információk gyakorlatilag nem léteznek. Megtalálható ugyan egy-két kép, amikor (vélhetőleg) a gyár kapuján kívül 4-5 személy (a közel 3000 alkalmazottból és bedolgozóból) épp fát ültet. Tekintettel az igen negatív, környezetet szennyező arculatára a cégnek ez inkább rossz vicc, mint CSR-akció. A honlapon még megtalálható egy sajtóközlemény, amelyből kiderül, hogy az Azomureş és Gheorghe Hagi Futballakadémia partneri szerződést írt alá.

Bár a cég több helyi sportklub támogatója, ennek bemutatásáról a vállalat a honlapon elfeledkezik. Ennek vélhető oka, hogy sem az összeg, sem a téma nem fontos számukra.

A nemrég kinevezett fiatal vezetőség, a cég korábbi gyakorlatától eltérő módon, formális partneri viszonyt kezdeményezett 2014 szeptemberében a város vezetőségével, és a 2015. decemberig történő beruházások bemutatása kapcsán a sajtó fele is némileg nyitott ugyanebben a periódusban. Bár a beruházások több százmillió eurós értékre rúgnak, s szinte kivétel nélkül a környezetvédelemmel hozhatók kapcsolatba, a vállalat inkább a hatóságok által megfogalmazott elvárásoknak akar megfelelni retorikai szinten is-, s távolról sem látszik a felelősségérzet a város lakosai, esetleg a saját alkalmazottaik iránt.

Ezenfelül a vállalat és a környezete közötti kommunikáció a jogszabályok által megkövetelt környezetvédelmi, biztonsági, munkavédelmi kommunikációra szorítkozik. A honlapon ezek megtalálhatók, így például a minőségre, a környezetvédelemre és a nagy balesetekre vonatkozó kötelezettségvállalás is. Ezek egyértelmüen a normatívák által megfogalmazott kényszerüségből vannak jelen. Mindegyik dokumentum önmagában semmire nem használható, legfeljebb egy auditor számára egy ,pipát” jelentenek a kötelező dokumentumok jegyzékében.

Szöges ellentétben az Azomureş vegyi kombináttal, az anyavállalat honlapján [9], a mindössze 12 szóösszetételt tartalmazó nyitó oldalon, az „Ameropa” szó háromszor, a „,social responsibilty” kétszer jelenik meg! További három szó „integrity”, „fairness” és „Foundation” szintén a felelősségtudatú vállalatra utaló fogalom. 


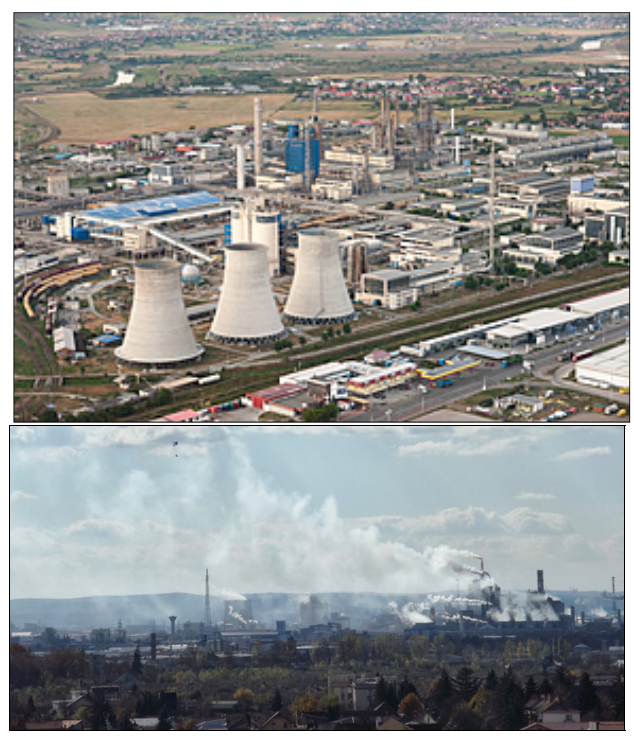

3. ábra. Az Azomureş vállalat karbantartási idöszakban és müködésben (forrás felsö kép www.azomures.com, alsó kép http://andreeasoft.blogspot.com)

Ennek a szembetűnő hangsúlykülönbségnek az a vélhető oka, hogy egy apró kommunikációs hiba óriási presztízs- és ebből kifolyólag egyben óriási pénzügyi veszteséget is jelenthet egy vállalat számára. Ebben a szektorban történt botrányok rávilágítottak a vállalatok sebezhetőségére, és fokozódott a tudatosság a vállalati magatartásminták tekintetében. Egyre kevésbé hagyható figyelmen kívül a különböző nyomásgyakorló csoportok (média, fogyasztók, környezetvédők, munkavállalók, politikai aktivisták, civil szervezetek) heves, gyors és hangos fellépése a vegyipari vállalatokkal és nem csak velük szemben.

Összegezve a fentieket, megállapítható, hogy az Azomureş esetében, mint igen érzékeny tevékenységi területen tevékenykedő vegyipari vállalatnál, ahol minden bizonnyal megfelelően kezelik a technológiából adódó veszélyeket, az egészségvédelemmel kapcsolatos felelősségvállalás kérdésében sokkal nagyobb nyilvánosság és elkötelezettség lenne elvárható. A nemzetközi szinten jelen levő különböző nyomásgyakorló csoportok egy kisváros szintjén, vagy nincsenek jelen, vagy nem elég hatékonyak.

\subsection{Richter Gedeon gyógyszergyár}

Az előző vegyipari vállalathoz valamelyest közelálló területen, a gyógyszeriparban, tevékenykedik az elemzésünkben szereplő második nagyvállalat.

A nemzetközi piacokon is igen ismert magyarországi anyavállalathoz tartozó marosvásárhelyi cég, a Gedeon Richter Romania SA a rendszerváltás előtti években épült Marosvásárhely belvárosában, ARMEDICA néven. A Richter cégcsoport tagjává, privatizációs folyamat eredményeként 1998-ban vált.

A cég honlapját elemezve megállapítható, hogy a cég eleget tesz annak a minimális elvárásnak, hogy bizonyságot tegyen - sajnos itt is csak egy formális nyilatkozat formájában-, a környezetvédelemre vonatkozó kötelezettség-vállalásáról.[10] Ugyanitt, egy szintén viszonylag ,házi feladat”-szerü tájékoztatásból megtudhatjuk a szervezet felelösségtudatát a tudomány és az oktatás irányába és ennek a támogatásáról. Itt végre, kissé elrejtve, akár pár konkrétum is megtalálható.

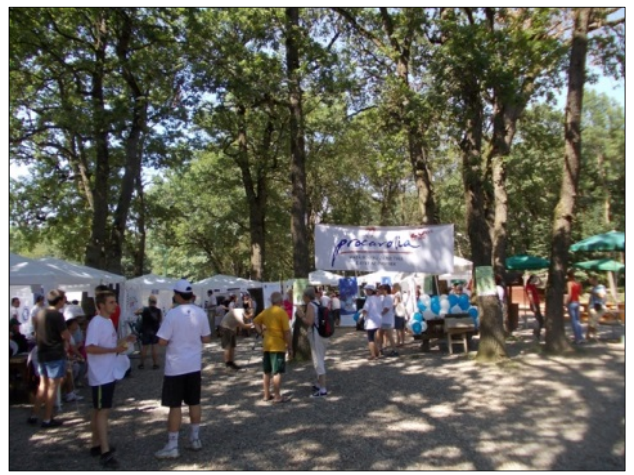

4. ábra. A Richter támogatja egy civil szervezet egészségmegörzö programját (forrás www.zi-de-zi.ro) 
Ezzel a rövid kis tájékoztatóval akár dicséretet is érdemelhetne a vállalat, hiszen olyan CSR-szerü tevékenységet tud felmutatni, mint amilyent a városban müködő nagyvállalatok többsége nem.

A 4. ábrán látható eseményen a gyógyszergyár anyagilag is támogatta a ProCardia alapítvány ,100méter az egészségért” projektjét. A partnerség nem jelenik meg a cég honlapján, pedig ez egy ,igazi” CSRmomentum.

A gyógyszergyárnak szánt dicséret szinte elhamarkodottnak mondható, ha megnézzük ebben az esetben is az anyavállalat honlapját. Ehhez képest, bizony nagyon halovány a marosvásárhelyi vállalat CSRtevékenysége. A Richter Gedeon Nyrt honlapján [11], végre megtaláltuk azt a CSRtevékenységet, amelyet 300 marosvásárhelyi cégnél kerestünk, $\mathrm{s}$ nem találtunk: a munkahelyi egészségre és biztonságra vonatkozó felelősségvállalást. Kis kereséssel még konkrétumokról is beszámolnak a budapestiek.

Összegezve a fentieket, megállapítható, hogy az Gedeon Richter Romania esetében érzékelhető, hogy (hasonlóan a nemzetközi viszonyokhoz) a felelősségvállalásban a gyógyszeripar előbbre áll más iparterületekhez képest, és helyi szinten részben az anyavállalat, részben a helyi piaci viszonyok hatására létezik CSR tevékenység.

A dolgozat terjedelme nem engedi meg a többi nagyvállalat elemzésének a bemutatását, de Gedeon Richter viszonylag szerény, de pozitív példája nem köszön vissza olyan nemzetközi szinten is jegyzett helyi vállalatoknál, mint a Dürkopp Addler, CIE Matricon, Mobex és mások. Ezeknél kivétel nélkül szinte semmi értékelhető tevékenység nem mutatható ki, pedig az első két esetben létezik egy transznacionális anyavállalat, amelynek szintjén van értékelhető CSR-tevékenység.

\subsection{CNE Cernavoda}

A CNE Cernavoda vállalat nem más mint a román energetikai ipar talán legnagyobb büszkesége, az ország egyetlen atomerőmüve. $\mathrm{Az}$ atomerőmü CSRtevékenységének az elemzése alapvetően két ok miatt került be a dolgozatba. Elsősorban azért, mert az alaptevékenysége veszélyesnek minősíthető lenne, ha nem tartanák be az igen szigorú szabályokat. Másodsorban azért mutatjuk be, mert semmilyen kapcsolata nincs az általunk elemzett populációval. Ez azért érdekes, mert az elemzés konklúziói, amennyiben hasonlóak lesznek az elemzett populáción tapasztaltakhoz, akkor feltételezhető, hogy nem a régió sajátosságával állunk szemben, hanem több romániai kisvárosra jellemző sajátosságról van ez esetben szó.

A CNE Cernavoda, közismertebb nevén a Cernavoda Atomerőmü, jogi értelemben a bukaresti S.N. Nuclearelectrica S.A. cég fiókvállalata. Az erőmü a maga 11Twh óra teljesítményével a hazai elektromos energiafogyasztás 20\%-át fedi le. A kb.93\%-os termelési kapacitás kihasználtságával a világ harmadik leghatékonyabb üzeme. Forrás: [12], [13].

Ha elemezzük az erőmü honlapját, megtalálhatjuk, hogy a vállalat elkötelezett a személyzet és a lakosság védelme érdekében az olyan veszélyekkel szemben, amelyeket egy ipari környezet, jelen esetben egy atomerőmű jelenthet. Ez az érdekes szóhasználat, „ipari környezet jelenthet” érdekes módon az Azomureş vállalat retorikájában is gyakran fellelhető, enyhén jelezve azt, hogy nem az ő hibájuk és felelősségük, hogy egy lakott terület közelében folytatnak veszélyesnek is minősíthető tevékenységet. Az Atomerőmü honlapját elemezve megállapítható, hogy a vállalat a munka- és egészségvédelem területén a hazai és nemzetközi jogszabályok, illetve a szakma gyakorlatából származó óvintézkedéseket teszi meg a saját és a partnerek al- 
kalmazottai védelmének érdekében. Ennyi és semmi több. Söt ebben az igyekezetében is hivatkozik a gazdasági hatékonysági szempontok figyelembevételére.

Elemezve a honlapot megállapítható, hogy a vállalat minden bizonnyal törekszik a jogszabályok betartására - erre vonatkozóan kimerítő tájékoztatást is ad -, de hogy a társadalmi felelősségvállalás terén fogalma sincs, mi a feladata, az nem kétséges. A kötelező munka- és egészségvédelmi jogszabályok betartása, pontosabban az ebből fakadó tájékoztatási kötelezettségeknek eleget téve, a tájékoztató szövegböl egyértelmüen látszik a megfelelési kényszer, a puszta formalitás. Nyoma sincs a felelősségérzetnek, de még a PR-fogásoknak sem.

Ezzel szemben a bukaresti anyavállalat esetében világosan látható, hogy a CSR tevékenységek bemutatása igen fontos a számukra. Olyan CSR-projekteket is felsorolnak, amelyek az atomerőmüvel kapcsolatosak, de a leányvállalat honlapján nem szerepelnek (lásd 5. ábra, ahol a CNE Cernavoda által épített híd látható, ez a CSRprojekt kifelejtődött az erőmü honlapjáról), illetve olyanokat is felsorolnak CSRprojektként - mint például élelmiszer-üzlet létesítése a gyár területén -, amelyek csak jóindulattal tekinthetők CSR-jellegü tevékenységnek.

\section{Következtetések}

A tanulmányozott vállalatok esetében az a feltételezés, úgy tünik, nem igazolódott be, mely szerint a nagyvállalatok érzékenyebbek a vállalati felelősségvállalás kérdésében. Ezek a vállalatok nem mutattak számottevő eltérést az eredeti - lényegesen nagyobb- KKV-ket tartalmazó mintához képest. Ez elörevetít egy eredetileg elhanyagolt tényezőt: a tevékenység lebonyolításának környezetét. Mivel a CSR-politika részben egy reakció a vállalat részéről a társadalom által gyakorolt hatásra, amenynyiben ez a hatás kismértékben nyilvánul meg, ez esetben a reakció elmarad. Ezt látszik igazolni, hogy a két kisvárosban, Marosvásárhelyen és Cernavodán, az elemzett vállalatok szinte semmilyen érdemlegeset nem kívántak tenni a CSR területén, ugyanakkor ugyanaz a vállalat más környezetben igen fontosnak tartja jelezni valamely közérdeklődésnek örvendő kérdésben a szerepvállalást. A cernavodai esetben vélhetőleg a fővárosi „nyomás” hatására történtek CSR-projektek, de ezek inkább voltak érdekesek a fóvárosnak, mint a helyi lakóknak. Egyébként elemezve a helyi sajtót nem találtunk arra vonatkozóan adatot, hogy esetleg az lenne az ok, hogy a helyiek úgy élik meg ezeket a projekteket, hogy ez nekik jár, tehát nem egy önként vállalt, felelősség, hanem egy korábbi alku következménye.

A vállalati felelösségvállalás a szakirodalomban eddig elsősorban a nagy és multinacionális vállalatokra jellemző elkötelezettséget jelentenek.

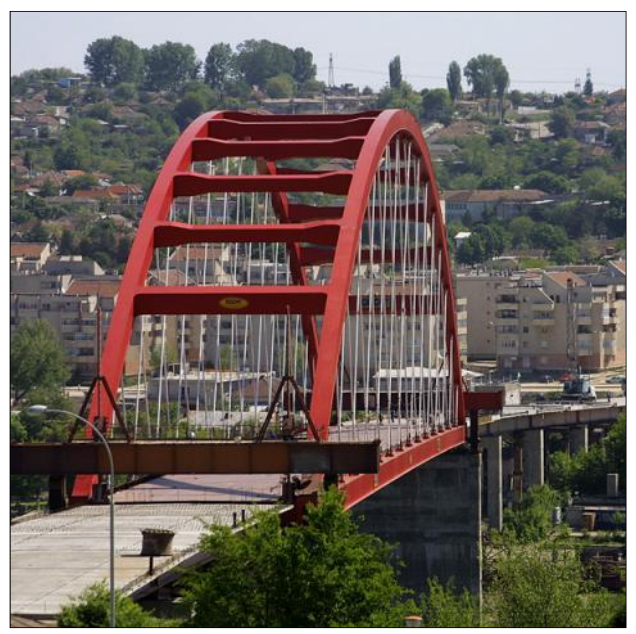

5. ábra. A CNE Cernavoda által épitett híd, mint CSR-projekt.

Ez a kutatás rávilágított arra, hogy nemcsak a vállalat mérete vagy multinacionális jellege a meghatározó, hanem az is, milyen 
elvárásai vannak annak a közösségnek, ahol kifejtik tevékenységüket. Függetlenül a termelési folyamat veszélyes jellegétől vagy a foglalkozási megbetege-dések megjelenésének valószínüségétől, ezek a vállalatok akkor tanúsítanak a jogszabályok feletti felelősségvállalást, ha ezek piaci elvárásokká lépnek elő, vagy a civilek nyomása számottevő.

A CSR-technikák hiánya nem feltétlenül a szándékos (?!) vagy a felelőtlen hozzáállás eredménye, hanem annak, hogy a társadalmi felelősség még nem jól felfogott anyagi érdek. A CSR politika által olyan potenciális előnyők érhetők el, mint a javuló vállalati arculat, a márka felértékelődése vagy az, hogy a vállalat vonzóbb lesz a jó szakemberek és a képzett munkaerő számára, s a cégnek könnyebben sikerül megtartania az értékes dolgozóit. Mindezek nem jelennek meg a társadalmi igény megfogalmazódása előtt. A jó kapcsolat a közösséggel, a médiával vagy a ható-ságokkal akkor válik igazán értékké, ha ez mindkét fél számára nyilvánvaló.

Ez esetben ameddig a civil érdekcsoportok nem erösödnek meg, a tudatos fogyasztók tömeges megjelenése nem lehetetleníti el a társadalmilag felelötlen vállalatokat, addig nem várható általános változás ezen a téren.

\section{Szakirodalmi hivatkozások}

[1] ${ }^{* * *} A$ vállalati társadalmi felelösségvállalásra vonatkozó megújult uniós stratégia (2011-2014). Brüsszel, 2011.10.25. COM (2011) 681 végleges. http://eur-lex.europa.eu/ LexUriServ/LexUriServ.do ?uri =COM:2011: 0681:FIN:HU:PDF, 2011. november 18

[2] *** Green paper - Promoting a European framework for Corporate Social
Responsibility. Commission of the European Communities, Brussels, 18.7.2001, $\operatorname{COM}(2001) 366$ final http://eurlex.europa.eu/LexUriServ/LexUriServ. do?uri=CELEX:52001DC0366:EN:HTML, megtekintve 2011. november 18.

[3] Bakos, L.: Survey on Managerial Attitudes Regarding CSR in the Case of SMEs. International Conference of Management and Industrial Engineering, ICMIE 2013, Bucureşti, 2013 ISSN 2344-0937, 115-123.

[4] Bakos, L.: Decision making and managerial attitude regarding Corporate Social Responsability in the case of Small and Middle Sized Companies. Challenges and Innovation in Management and Innovation, SIM2013, Timişoara,

http://www.sciencedirect.com/science/article/ pii/S187704281402031X

[5] Baleanu, T., E., Chelcea, L., Stancu, A.: The Social Responsibility Of The Top 100 Romanian Companies. An Analysis Of Corporate Websites. Amfiteatru Economic, Volume: 13 Issue: 29 Pages: 235-248. Published: 2011

[6] Kun A.: A multinacionális vállalatok szociális felelössége - CSR-alapú önszabályozás kontra (munka)jogi szabályozás. Ad Librum, Budapest, 2009, ISBN: 978-963-9888-86-9

[7] Studiu privind implicarea companiilor din România în activități de „Responsabilitate Socială Corporatistă". POSDRU/93 /3.3/S/62346 pályázat, koordináló szerv: Bukaresti Kereskedelmi, Ipari és Mezőgazdasági Kamara

http://www.centras.ro/ro/proiecte/parteneriat -pentru-dezvoltare-posdru-93-3-3-s62346.html

[8] www.azomures.com, 2014. október 24.

[9] www.ameropa.com, 2014. október 24.

[10] www.gedeon-richter.ro, 2014.október 24.

[11] www.richter.hu, 2014.október 24.

[12] www.nuclearelectrica.ro, 2014.október 24.

[13] www.cne.ro 